\title{
The Importance of Accounting and Fair Value Measurements in IFRS 9 in Achieving the Quality of Accounting Information Disclosed in Private Banks
}

\author{
${ }^{1}$ Fedaa Abd Almajid Sabbar Alaraji, ${ }^{2}$ Zaid Yaseen Saud Al-Dulaimi and ${ }^{3}$ Thamer \\ Mahdi Muhamed Sabri \\ ${ }^{1}$ Al-Mustansiriyah Presidency University, Iraq, Craiova University, Faculty of Economics and \\ Administration, Craiova, Romania \\ ${ }^{2}$ University of Economic Studies, Bucharest, Romania \\ ${ }^{3}$ Ministry of Higher Education, Baghdad, Iraq
}

Correspondence should be addressed to: Fedaa Abd Almajid Sabbar Alaraji; fdaasabbar@yahoo.com

Received date: 12 February 2018; Accepted date: 07 June 2018; Published date: 01 August 2018

Academic Editor: Camelia Hategan

Copyright (C 2018. Fedaa Abd Almajid Sabbar Alaraji, Zaid Yaseen Saud Al-Dulaimi and Thamer

Mahdi Muhamed Sabri . Distributed under Creative Commons CC-BY 4.0

\begin{abstract}
our current study aims to highlight the importance of accounting and fair value measurements in accordance with IFRS 9 (Financial Instruments Measurement and Classification) in Private Banks in Iraq and their role in achieving the qualitative financial information in their financial statements. Subsequently, the study states the most important problems and obstacles faced by the banking environment in Iraq in the application of this standard. To achieve the objectives of the study and to test the hypotheses a poll was applied to a sample of directors in Iraqi private banks and a sample of professors to collect their views on the matter. The study is based on the descriptive statistical analysis method for the analysis of the study variables and for testing the hypotheses. The most important results of the study were the lack of sufficient awareness on the importance of applying the accounting and fair value measurement in adopting and applying the international standard (9) in the production and disclosure of financial information. There are also issues facing the process of implementation as the study reached several recommendations, the most important of which is the need to provide the legislative and professional environment necessary to adopt and apply accounting and fair value measure and meet the international standard number 9.
\end{abstract}

Keywords: standards, measurement and classification, disclosure, fair value.

Cite this Article as: Fedaa Abd Almajid Sabbar Alaraji, Zaid Yaseen Saud Al-Dulaimi and Thamer Mahdi Muhamed Sabri (2018), "The Importance of Accounting and Fair Value Measurements in IFRS 9 in Achieving the Quality of Accounting Information Disclosed in Private Banks" The MENA Journal of Business Case Studies, Vol. 2018 (2018), Article ID 311783, DOI: 10.5171/2018.311783 


\section{Introduction}

The present economic context is characterized by fast changes, economic mass between countries, globalization and the orientation of countries towards economic correlation. This entire context has an impact on accounting and financial reporting which was reflected in the issuance of IFRS standards, particularly standard no. 9 (Financial instruments: measurement and classification), which implements and applies fair value accounting as a measurement and classification tool. The state of Iraq aspires to match the international economic developments and to be integrated in the international economic, financial, accounting and auditing contexts in accordance with the international relevant standards in this field (IFRS) in order to achieve a competitive economy and to provide a favorable and attractive business environment at local and international levels. The implementation of IFRS 9 in Iraqi private banks and the accounting of fair value is one of the most important requirements that need to be implemented in Iraq In this regard, our study aims at identifying the appropriateness of the banking environment - the private sector in applying the fair value accounting as a tool for measuring and classifying financial assets and liabilities. It is important to underline the advantages of disclosure and financial reporting for users of this information when applying fair value accounting. The study is divided into five sections, the first one includes the introduction of the study, the second section covers the literature review and the third one presents the methodology of the study. The fourth section includes the discussion and the results, and the fifth section presents the conclusions and recommendations.

\section{Literature Review}

The study of Zyod \& Roda (2007) aimed at showing the shortcomings of the published financial statements, their inefficiency and the necessity of preparing them in accordance with the International Accounting Standard No. 30. The study reached several conclusions, including the insufficient information that was disclosed in the financial reports of the banks.

The study of Mater \& Nor (2009) examined the validity of the charges against accounting standards at fair value as the main cause of the global financial crisis. The study reached several conclusions, including that the global financial crisis affected all sectors in terms of the impact of banks as mediators for all sectors and found that fair value standards are not related to causing the crisis. The study does not recommend abandoning these standards.

The goal of the study of Awad (2010) was to uncover the impact of fair value accounting on the global financial crisis and the impact of fair value accounting on the occurrence of the crisis. The study reached several results, the most important of which are the repercussions of the financial crisis on commercial banks in Jordan and consequently the policies adopted by the government. This crisis at the national economy was the reason for the decline in the value of banking facilities provided by Jordanian commercial banks to the business sector.

The study of Linda \& Pederson (2011) compared the requirements of IAS 39 and the requirements of Standard No. 9 for banks that have the largest share of loan facilities granted in Denmark according to the criteria of the Danish Financial Supervisory Authority. The main conclusions of the study are the existence of significant differences resulting from the change in the admission entitlements and that impairment of financial assets requires the determination of appropriate accounting and financial systems to measure this change in recognition and measurement.

The study of Christensen \& Nikolaev (2013) concluded that IFRS standards allowed companies to choose between the 
historical cost and the fair value of nonfinancial assets (buildings and equipment) with the obligation to consistently disclose the accounting policy used.

The main objective of the study of Arnaouq, Bahaa Ghazi (2014) is to determine the effect of applying IFRS 9 on financial instruments available for sale, financial instruments held for trading, financial instruments held to maturity, in the context of the Central Bank of Damascus having to identify techniques for measuring fair value.

What distinguishes our current study is that it follows the application of IFRS 9 Financial Instruments: Measurement and Classification in Iraq from the fiscal year 2016 and the importance of this topic in the banking environment - the private sector in Iraq alongside the challenges, constraints and difficulties facing the application process.

\section{Methodology}

\section{The Problem of the Study}

The problem of the study is the lack of harmonization of the accounting environment in Iraq in general and the banking environment in particular in the adoption and application of fair value accounting required for the application of IFRS 9 (Financial Instruments: Measurement and Classification) for banks. They face challenges and difficulties as well as a lack of awareness of the importance and quality of information resulting from the application of fair value accounting.

\section{Study Objective}

Our study aims to achieve the following objectives:

Highlight the appropriateness of the banking environment - the private sector in Iraq - in adopting and applying the fair value accounting as a requirement for the implementation and application of IFRS 9 (Financial Instruments: Measurement and Classification).
Emphasize the impact of the application of fair value accounting on the financial reporting and on the quality of the financial information disclosed in the financial statements.

\section{Hypotheses of the Study}

The study is based on the following hypotheses:

- The adoption and application of fair value accounting in the banking environment - Iraqi private sector - in accordance with the requirements of IFRS 9 (Financial Instruments: Measurement and Classification) faces challenges, constraints and difficulties.

- The application of fair value accounting in the private banking environment - Iraqi private sector - would improve and develop the quality, objectivity and accuracy of the information available through the financial reporting process of these banks.

\section{Study Determinants}

We have relied on the opinion of a sample of managers of private banks in Iraq and a sample of academic professors in the field of international financial reporting standards. In fact, there are other parties benefiting from the financial information disclosed in the financial statements such as investors, customers of the banks, tax departments and other parties. The scope of the fair value measure for the application of IFRS 9 is difficult to identify.

\section{Results and Discussion}

\section{The Concept of Fair Value and Its Development}

According to the international standard IFRS 13 (fair value measurement), the fair value is the price that can be obtained as a result of the sale of an asset or a payment to convert a liability under a regular process between market participants on the measurement date. The International 
Standards Committee (IVSC) defined the fair value as an estimate in which an asset can be exchanged at the valuation date between a willing buyer and seller and a neutral market so that each entity has sufficient and free information to complete the transaction (Safwan \& Asma, 2013).

Fair value covers the following aspects (Lutamila, 2009):

- Fair value refers to values that are obtained directly from prices quoted in active markets

- Fair value refers to values that can be observable in clear market data

- Fair value refers to values determined using internal valuation models.

\section{Justification of the Trend towards Fair Value Accounting}

The fast economic developments in recent years, the emergence of globalization, economic blocs, multinational companies, the removal of economic barriers and the encouragement of foreign investment have influenced the profession of accounting and auditing through the need to adapt the profession to the new economic reality in order to meet the needs of beneficiaries of financial information disclosed in the financial statements. Although the historical cost accounting principle is consistent with the accounting assumptions and principles, it has faced criticism about the limited usefulness of the financial information disclosed in the financial statements. The value recorded and disclosed has become obsolete in most of the economies of the world suffering from inflation and thus the information disclosed lost its validity and ability to reflect the real financial situation of the companies. In this context, investors are seeking to obtain fair and honest information that reflects the actual and real financial reality of companies. The rapid economic developments have resulted in products with new labels and terms imposed by these changes, including financial instruments from companies, bonds, certificates of deposit and other items of assets and liabilities. The use of derivative financial instruments including forward contracts, swaps, options and other rights has led to the expansion and ramification in the use of financial instruments and to the development of risk management tools to identify, hedge and mitigate their effects. Hence, the importance of fair value accounting as an ideal alternative to the convergence of economic values and accounting values, as fair value accounting information is accurate, reliable and complete in quantity, quality and timely introduction. Professional organizations have found that fair value accounting is most appropriate for financial reporting purposes in relation to contingent liabilities. Financial instruments correlate financial instruments including financial derivatives by estimating their fair value and showing them in the balance sheet. These professional organizations have issued several international accounting standards such as IAS 32 Presentation and Disclosure Performed in 1996 and IAS 39 on Recognition and Measurement, which has been in effect since 2001. The latest standard issued is the International Financial Reporting Standard No. 9 for Measurement and Classification, which has been phased in as of 2014 .

\section{International Accounting Standards Oriented To Fair Value}

As a result of the reasons and justifications discussed in the justification for the trend towards fair value accounting, this trend was accompanied by the issuance of professional accounting standardsrelated to fair value accounting, as follows:

- FASB issued Standard No. (115) of 1993 regarding disclosure and presentation

- IASB issued in 1995 the revised IAS 32 (Financial Instruments: Presentation, Disclosures and Adjustments in 2003, 2004, 2005 and 2006)

- In 2007, IFRS issued IFRS 7 Financial Instruments: Disclosures

- IASB issued in 1999 the revised IAS 39, "Financial Instruments: 
Recognition and Measurement" for banks

- IFRS issued in (2009): Financial Instruments: Measurement and Classification, amended in 2010, 2011 and 2013, which is required to be fully implemented by the beginning of 2018. The importance of this standard is that it represents a correction of the negative effects of fair value accounting rather than historic value in the recording of assets and liabilities, which is a qualitative shift from the system based on a clear decline in the value of the asset to the future estimate of losses.

\section{The Impact of Applying Fair Value on the Quality of Accounting Information}

Paragraph (78) of IAS 32 states that fair value information is useful in making decisions by users of financial information in the financial statements through the following areas (Fanjan, 2011):

- Fair value provides a neutral basis for assessing the efficiency of funds management by clarifying the effects of the purchase, sale and retention of financial assets decisions, and the carrying or retention of financial liabilities

- Fair value information is used to compare between financial instruments that have the same economic characteristics, despite the difference of purpose and the date of issue and purchase

- The estimate of financial markets reflects the present value of the expected cash flows of the instruments.

The FASB has urged the use of the fair value measurement in the financial statements because fair value information is appropriate to all investors and lenders compared to historical cost information because the fair value measurements better reflect the current financial position of the reporting company and its disclosures. It also provides easy methods for assessing their past performance and future prospects (Jamil, 2013).

\section{Fair Value Accounting In the Iraqi Environment}

The unified accounting system for selffinancing private Iraqi companies, in addition to the unified accounting system for self-financing banks and private insurance companies, was adopted. These two systems were not based on a fair value accounting model. The historical cost model was adopted but the accounting professional environment in Iraq did not apply the fair value accounting at the level of application and legislation and only introduced the subject of accounting fair value theoretically in the academic and professional studies at the level of preliminary studies. Since 2016, at the Iraqi Central Bank instruction, private banks have been required to adopt and apply IFRS 9 (Financial Indicators: Measurement and Classification) through the preparation of the financial statements banks based on the fair value accounting principles. However, these banks faced challenges, difficulties and constraints in the actual application.

\section{Applied Field Study}

For the purpose of completing the applied field study, the banking community was selected, and a sample of this community was extracted, consisting of directors of private banks (30), external auditors of the private banks (30) and academic professors specialized in the field of banking accounting (10). The sample was distributed a questionnaire. The statistical program (SPSS) was used to analyze the views of the sample population using the methods of mean and standard deviation, as well as using one sample t-test in the hypothesis test.

\section{Testing the First Hypothesis}

The application of fair value accounting in the private banking environment - the private sector in Iraq would improve and develop the quality of the characteristics of 
financial information and objectivity and veracity of the financial reporting of these banks.

Table 1 shows the statistical averages and standard deviations of the study sample on the effect variable, the relationship between fair value accounting, the quality of the characteristics of the financial information, and the accuracy and objectivity of the financial reporting.

Table 1: Results of analysis of the first hypothesis test

\begin{tabular}{|c|c|c|c|c|}
\hline No. & Statement & $\begin{array}{l}\text { Arithmetic } \\
\text { mean }\end{array}$ & $\begin{array}{l}\text { Standard } \\
\text { deviation }\end{array}$ & $\begin{array}{c}\text { Answer } \\
\text { direction }\end{array}$ \\
\hline \multicolumn{5}{|c|}{ Appropriate property } \\
\hline 1 & $\begin{array}{l}\text { The financial statements prepared in } \\
\text { accordance with fair value accounting assist } \\
\text { creditors in making credit decisions. }\end{array}$ & 2.82 & 0.194 & agree \\
\hline 2 & $\begin{array}{l}\text { The use of fair value accounting leads to the } \\
\text { presentation of financial information in a } \\
\text { more useful and beneficial way to investors in } \\
\text { the stock market. }\end{array}$ & 2.62 & 0.420 & agree \\
\hline 3 & $\begin{array}{l}\text { The fair value of the financial statements } \\
\text { results in the fact that their information is of } \\
\text { greater benefit to the users of those financial } \\
\text { statements than on the basis of historical cost. }\end{array}$ & 2.73 & 0.321 & agree \\
\hline 4 & $\begin{array}{l}\text { Financial statements prepared on the basis of } \\
\text { fair value accounting provide information that } \\
\text { has a very high predictive capacity. }\end{array}$ & 2.65 & 0.484 & agree \\
\hline 5 & $\begin{array}{l}\text { The financial statements prepared on the basis } \\
\text { of fair value accounting have the proper timing } \\
\text { of the accounting information as they reflect } \\
\text { the recent fair valuation of the items of the } \\
\text { financial statements. }\end{array}$ & 2.46 & 0.55 & agree \\
\hline 6 & $\begin{array}{l}\text { That financial analysis indicators based on fair } \\
\text { value accounting are more useful in the } \\
\text { decision-making process. }\end{array}$ & 2.58 & 0.593 & agree \\
\hline 7 & $\begin{array}{l}\text { The financial statements prepared on the basis } \\
\text { of fair value accounting reflect the economic, } \\
\text { social, political, technical and other changes } \\
\text { affecting the market as the market price is a } \\
\text { reflection of all changes. }\end{array}$ & 2.22 & 0.723 & neutral \\
\hline & $\begin{array}{l}\text { Mean arithmetic averages and standard } \\
\text { deviations of the appropriate property. }\end{array}$ & 2.46 & 0.55 & agree \\
\hline \multicolumn{5}{|c|}{ Reliability property } \\
\hline 8 & $\begin{array}{l}\text { Reporting and disclosing financial information } \\
\text { in accordance with fair value accounting } \\
\text { increases confidence in the financial } \\
\text { statements presented and disclosed. }\end{array}$ & 2.46 & 0.641 & agree \\
\hline 9 & $\begin{array}{l}\text { That the financial statements in accordance } \\
\text { with fair value accounting would result in } \\
\text { neutral information. }\end{array}$ & 2.51 & 0.615 & agree \\
\hline 10 & $\begin{array}{l}\text { The financial statements prepared on the basis } \\
\text { of fair value accounting can be verified by the }\end{array}$ & 2.54 & 0.537 & agree \\
\hline
\end{tabular}




\begin{tabular}{|c|c|c|c|c|}
\hline & $\begin{array}{l}\text { management or by any party outside the } \\
\text { company. }\end{array}$ & & & \\
\hline 11 & $\begin{array}{l}\text { Financial statements prepared in accordance } \\
\text { with fair accounting are more reliable than } \\
\text { that on historical cost basis. }\end{array}$ & 2.57 & 0.67 & $\overline{\text { agree }}$ \\
\hline 12 & $\begin{array}{l}\text { The financial information arising from the } \\
\text { measurement of financial assets and liabilities } \\
\text { under fair value accounting is highly reliable. }\end{array}$ & 2.66 & 0.484 & agree \\
\hline 13 & $\begin{array}{l}\text { An assessment of the elements of the financial } \\
\text { statements in accordance with fair value } \\
\text { accounting would result in the accurate } \\
\text { representation of the accounting information. }\end{array}$ & 2.57 & 0.67 & agree \\
\hline 14 & $\begin{array}{l}\text { Fair value financial statements provide } \\
\text { information for the reconciliation of the } \\
\text { interests of the various categories of users of } \\
\text { the financial statements. }\end{array}$ & 2.62 & 0.578 & agree \\
\hline & $\begin{array}{l}\text { Mean arithmetic averages and standard } \\
\text { deviations related to reliability. }\end{array}$ & 2.52 & 0.308 & agree \\
\hline \multicolumn{5}{|c|}{ Understandable property } \\
\hline 15 & $\begin{array}{l}\text { The use of fair value would provide full } \\
\text { information on the performance indicator and } \\
\text { therefore the financial report would be more } \\
\text { understandable. }\end{array}$ & 2.54 & 0.606 & agree \\
\hline 16 & $\begin{array}{l}\text { The use of fair value accounting increases the } \\
\text { susceptibility to accounting information in the } \\
\text { financial statements. }\end{array}$ & 2.54 & 0.458 & agree \\
\hline 17 & $\begin{array}{l}\text { That the financial statements prepared on a } \\
\text { fair value basis are more readily } \\
\text { understandable than those prepared on a } \\
\text { historical cost basis. }\end{array}$ & 2.51 & 0.789 & agree \\
\hline 18 & $\begin{array}{l}\text { Financial reports should include all the difficult } \\
\text { and complex financial information understood } \\
\text { by the average user. }\end{array}$ & 2.42 & 0.626 & neutral \\
\hline 19 & $\begin{array}{l}\text { The application of fair value accounting results } \\
\text { in clear accounting information that is not } \\
\text { clear, complex and clearly classified. }\end{array}$ & 2.58 & 0.441 & $\overline{\text { agree }}$ \\
\hline & $\begin{array}{l}\text { Mean arithmetic averages and standard } \\
\text { deviation. }\end{array}$ & 2.57 & 0.367 & agree \\
\hline \multicolumn{5}{|c|}{ Comparability property } \\
\hline 20 & $\begin{array}{l}\text { The use of fair value to access the return on } \\
\text { investment funds is feasible. }\end{array}$ & 2.55 & 0.766 & agree \\
\hline 21 & $\begin{array}{l}\text { That fluctuations in market prices allow for } \\
\text { comparisons between accounting information } \\
\text { arising from the fair value application. }\end{array}$ & 2.62 & 0.022 & $\overline{\text { agree }}$ \\
\hline 22 & $\begin{array}{l}\text { The financial statements prepared in } \\
\text { accordance with fair value accounting are } \\
\text { better than those prepared on the historical } \\
\text { cost basis. }\end{array}$ & 2.19 & 0.362 & agree \\
\hline 23 & $\begin{array}{l}\text { When applying fair value accounting for the } \\
\text { first time, the financial statements will achieve } \\
\text { the comparative advantage of accounting } \\
\text { information. }\end{array}$ & 2.58 & 0.523 & agree \\
\hline
\end{tabular}




\begin{tabular}{|c|l|l|l|l|}
\hline 24 & $\begin{array}{l}\text { The process of complying with the application } \\
\text { of fair value accounting and consistency in the } \\
\text { use of relevant standards helps make the } \\
\text { financial statements disclosed and published } \\
\text { comparable. }\end{array}$ & $\begin{array}{l}\text { Average mean and standard deviation of the } \\
\text { concept of comprehensibility. }\end{array}$ & 2.56 & 0.676 \\
\hline $\begin{array}{l}\text { Arithmetical averages and standard deviations } \\
\text { of the hypothesis. }\end{array}$ & 2.52 & 0.344 & agree \\
\hline
\end{tabular}

Source: Statistical analysis of applied study data.

The results of the statistical analysis in Table 1 show that there is a relationship between the application of fair value accounting and the quality of the accounting information available in the financial statements from the point of view of the sample of the study as the mean is 2.57 and the standard deviation is 0.328 . Also, there is a relationship between the application of fair value accounting and the increased reliability of the accounting information disclosed in the financial statements, as the mean is 2.52 and the standard deviation is 0.308 . As to the effect of applying fair value accounting on the disclosure of accounting information, consent to the ability to understand information when applying fair value accounting, as the mean is 2.57 and the standard deviation is 0.367. The respondents agreed that the application of fair value accounting in private banks in Iraq will make the financial statements and information disclosed comparable. The mean is 2.56 and the standard deviation is 0.421. The mean averages of the hypothesis reached 2.52 and the standard deviation (0.344) and this result indicates that the impact and relationship in applying fair value accounting in accordance with IFRS 9 will maximize and improve the quality of financial information published and disclosed in the financial statements.

The second hypothesis test: the adoption and application of fair value accounting in the banking environment - the Iraqi private sector in accordance with the requirements of IFRS 9 Financial Instruments: Measurement and Classification faces challenges, constraints and difficulties

Table 2: Results of analysis of the first hypothesis test

\begin{tabular}{|l|l|l|l|l|}
\hline No & \multicolumn{1}{|c|}{ Statement } & \multicolumn{1}{c|}{$\begin{array}{c}\text { Arithmetic } \\
\text { mean }\end{array}$} & \multicolumn{1}{c|}{$\begin{array}{c}\text { Standard } \\
\text { deviation }\end{array}$} & \multicolumn{1}{c|}{$\begin{array}{c}\text { Answers } \\
\text { direction }\end{array}$} \\
\hline 1 & $\begin{array}{l}\text { There is lack of awareness and } \\
\text { knowledge of the financial banking } \\
\text { community in the Iraqi } \\
\text { environment regarding the } \\
\text { application of fair value accounting } \\
\text { and its procedures }\end{array}$ & 2.62 & 0.578 & agree \\
\hline 2 & $\begin{array}{l}\text { Bank managers, accountants and } \\
\text { other stakeholders need to develop } \\
\text { their understanding of fair value. }\end{array}$ & 2.78 & 0.268 & agree \\
\hline 3 & $\begin{array}{l}\text { The banking accounting system in } \\
\text { the Iraqi environment is consistent } \\
\text { with fair value accounting as a basis } \\
\text { for application. }\end{array}$ & 1.87 & 0.812 & not agree \\
\hline 4 & $\begin{array}{l}\text { Trade unions, associations and } \\
\text { professional organizations in Iraq } \\
\text { do not play the necessary and } \\
\text { required role in the process of }\end{array}$ & 2.44 & 0.626 & agree \\
\hline
\end{tabular}




\begin{tabular}{|c|c|c|c|c|}
\hline & $\begin{array}{l}\text { education, training and adequate } \\
\text { rehabilitation to contribute to the } \\
\text { application of fair value accounting } \\
\text { in the Iraqi banking environment. }\end{array}$ & & & \\
\hline 5 & $\begin{array}{l}\text { The concept of fair value } \\
\text { accounting is not clear in the Iraqi } \\
\text { accounting environment in general } \\
\text { and the banking environment in } \\
\text { particular. }\end{array}$ & 2.46 & 0.479 & agree \\
\hline 6 & $\begin{array}{l}\text { Lack of qualified experts in the Iraqi } \\
\text { banking environment to determine } \\
\text { fair value in the absence of an active } \\
\text { market for the assets and liabilities } \\
\text { to be assessed. }\end{array}$ & 2.74 & 0.626 & agree \\
\hline 7 & $\begin{array}{l}\text { The Iraqi market is characterized } \\
\text { by monopoly and the impact of } \\
\text { government intervention. }\end{array}$ & 2.48 & 0.682 & agree \\
\hline 8 & $\begin{array}{l}\text { Prices are determined in the Iraqi } \\
\text { markets according to the law of } \\
\text { supply and demand without } \\
\text { external or governmental } \\
\text { influences. }\end{array}$ & 1.43 & 0.741 & not agree \\
\hline 9 & $\begin{array}{l}\text { Domestic legislation in Iraq plays an } \\
\text { important role in the difficulty of } \\
\text { using fair value accounting in the } \\
\text { Iraqi banking environment. }\end{array}$ & 2.49 & 0.626 & agree \\
\hline 10 & $\begin{array}{l}\text { The weakness of academic and } \\
\text { vocational curricula at the level of } \\
\text { primary and higher education in } \\
\text { the field of fair value accounting in } \\
\text { Iraq. }\end{array}$ & 2.50 & 0.741 & agree \\
\hline 11 & $\begin{array}{l}\text { The banking accounting system in } \\
\text { force in Iraq does not include fair } \\
\text { value accounting. }\end{array}$ & 0.74 & 0.322 & agree \\
\hline 12 & $\begin{array}{l}\text { The members of the banking } \\
\text { financial community differ in their } \\
\text { awareness of the importance and } \\
\text { bases of adopting fair value } \\
\text { accounting in the Iraqi banking } \\
\text { environment. }\end{array}$ & 2.58 & 0.593 & agree \\
\hline \multirow[t]{2}{*}{13} & $\begin{array}{l}\text { The opening of the banking market } \\
\text { towards international banks would } \\
\text { contribute to knowledge on fair } \\
\text { value. }\end{array}$ & 2.78 & 0.268 & agree \\
\hline & $\begin{array}{l}\text { Arithmetical averages and standard } \\
\text { deviations related to the hypothesis. }\end{array}$ & 2.51 & 0.238 & agree \\
\hline
\end{tabular}

Source: Statistical analysis of applied study data.

The results of the second hypothesis analysis in Table 2 show that there are challenges, obstacles and difficulties facing the application of fair value accounting in private banks in Iraq in accordance with the requirements of IFRS 9 Financial Instruments: Measurement and Classification. There was agreement of the study sample on the paragraphs of the questionnaire in terms of lack of awareness and knowledge by accountants in state and 
private banks in Iraq and weak academic curricula in the field of fair value accounting and the lack of active markets necessary to apply fair value accounting, alongside the absence of experts in the field of fair value accounting. The study sample also agreed on the effects of monopolies and government intervention in the banking markets as well as on the remaining paragraphs of the survey. The arithmetic average of the averages of the second hypothesis reached (2.51) while the standard deviation was (0.238).

Table 3 shows that the calculated value $(t)$ was 9.220 while the value of $(t)$ was calculated (2.069) i.e. the calculated value of $t$ is greater than the tabular value. Thus, the hypothesis is accepted. According to this hypothesis, the application of fair value accounting in the private Iraqi banks in accordance with the requirements of IFRS 9 will enhance and improve the quality of the accounting information published and disclosed in the financial statements and would generate predictive information, useful in credit decision making. The information is provided at certain times, is clear, valid, scalable and can be used for comparison with financial indicators. Table (3) shows that the calculated value of $(t)$ is 9.327 while the value of $t(t a b)$ is greater than the tabular value $(\mathrm{t})$. The hypothesis is accepted. According to this hypothesis, the application of fair value accounting in the Private Banking Environment According to the requirements of IFRS 9 (Financial Instruments: Measurement and Classification) is facing challenges in the banking industry. The Iraqi banking environment is constrained by fair value accounting and the members of the financial community vary in their opinions regarding the most important challenge between fair value accounting and the absence of local legislation required to apply fair value accounting.

Table 3: The calculated value $(t)$ and the moral level of each hypothesis

\begin{tabular}{|l|l|l|l|l|}
\hline \multicolumn{1}{|c|}{ Hypothesis } & \multicolumn{1}{|c|}{$\begin{array}{c}\text { Arithmetic } \\
\text { mean }\end{array}$} & $\begin{array}{c}\text { Calculated t } \\
\text { value }\end{array}$ & $\begin{array}{c}\text { Value t } \\
\text { significant } \\
\text { Sig-t }\end{array}$ & \multicolumn{1}{|c|}{$\begin{array}{c}\text { The answers } \\
\text { direction }\end{array}$} \\
\hline The first hypothesis & 2.50 & 9.327 & 0.000 & $\begin{array}{l}\text { Accept of the } \\
\text { hypothesis }\end{array}$ \\
\hline The second hypothesis & 2.57 & 9.220 & 0.000 & $\begin{array}{l}\text { Accept of the } \\
\text { hypothesis }\end{array}$ \\
\hline
\end{tabular}

Source: Statistical analysis of applied study data

\section{Conclusions and Recommendations}

\section{Conclusions}

In the light of theoretical and applied studies, the analysis of data and extraction of the results of the analysis, the study reached the following conclusions:

1. The Iraqi work environment (economic, financial, social, cultural and accounting) is currently not prepared for the implementation of IFRS 9, as the basic requirements are not available, such as integrated measurement systems, tools and databases on future prospects for credit risk, etc.
2. It is necessary that the relevant authorities in Iraq such as the Central Bank of Iraq and the Accounting and Auditing Standards Board in Iraq issue rules to facilitate the adoption and application of fair value accounting under IFRS 9.

3. The application of IFRS 9 in the Iraqi banking environment faces significant challenges in the availability of fair value data and other information related to forecasts.

4. The application of fair value accounting in private banks in Iraq in accordance with the requirements of IFRS 9 (Financial Instruments: Measurement and Classification) will maximize and improve 
the quality of the accounting and financial information published and disclosed in the financial statements. The application of fair value accounting would generate predictable information useful in the loan decision-making process in a timely manner and leading to accurate representation of the accounting information in the financial statements. Also, the information and financial indicators can be understood through clarity, lack of complexity, scalability and viability, being useful for generating comparisons.

5. There are challenges, obstacles and difficulties facing the application of fair value accounting in private banks in Iraq in accordance with the requirements of IFRS No. 9 concerning banks. These challenges, obstacles and difficulties are as follows:

- Lack of awareness of the bank managers and users of financial information in Iraq about fair value accounting and its importance in developing and improving the quality of accounting information published and disclosed in the financial statements.

- Weak academic and vocational curricula in Iraqi universities and institutes in the field of fair value accounting, from which will graduate the scientifically and practically qualified cadres to apply fair value accounting.

- The absence of an active and efficient financial market in the Iraqi environment, which is one of the tools to adopt and apply fair value accounting and the effects of government interventions in the banking markets.

- Lack of specialized accounting staff in fair value accounting.

- Lack of local legislation and accounting standard for the adoption and application of fair value accounting in private banks in Iraq.

- The application of fair value accounting is in opposition to some local laws, regulations and instructions in Iraq such as the Income Tax Law, the Companies Law and the Bank Accounting System adopted in Iraq based on the historical cost scale in the process of preparing financial statements for private banks in Iraq.

\section{Recommendations}

According to the conclusions of the study, the researcher makes the following recommendations:

1. The government agencies, such as the Ministry of Planning, the Central Bank and the Ministry of Commerce are responsible for providing the required data on future fluctuations and forecasts that affect the determination of fair value and the calculation of expected profits and losses.

2. Establish a culture of accounting and fair value measurement by the professional accounting organizations and bodies in Iraq through issuing specific criteria appropriate to the economic, financial and social reality in Iraq, as well as specific methods and mechanisms for measuring the fair value of financial assets and liabilities.

3. It is essential to highlight the importance of fair value accounting for the adoption and application of IFRS 9 (Financial Instruments: Measurement and Classification) and its role in maximizing and improving the quality of accounting information published in the financial statements by organizing seminars and workshops on fair value accounting.

4. It is important to issue legislation and professional accounting standards for the adoption and application of fair value accounting, which is required in the application of IFRS No. 9 concerning banks, and to eliminate conflicts with local laws, regulations and instructions.

5. Issue a new accounting system for banks or amend the current accounting system for banks in Iraq to suit the application of 
fair value accounting in private banks in Iraq, instead of the currently approved system based on historical cost calculation.

6. Progress on the issuance and amendment of academic curricula in the field of fair value accounting in order to obtain qualified human resources and scientific and practical manpower in the field of applying fair value accounting.

7. Provide the possibility to measure and display fair value efficiently and effectively.

\section{Proposed Future Studies}

Our study represents a new addition to the previous studies on the importance of accounting and fair value measurement and the application of IFRS 9 in private banks in Iraq for its role in producing high quality financial information. Our study can be completed with other studies proposed in the following fields:

- The importance of accounting and fair value measurements for the application of IFRS 9 on a sample of government and Islamic banks, which is a conceptual framework that differs from IFRS.

- The extent of awareness and recognition by other related parties of the concept of fair value measurement for the application of IAS 9, such as investors, internal and external auditors, and tax services.

-The relationship between fair value accounting and rationalization of decisions.

\section{References}

1. Awad, RW. (2010), 'Accounting of Fair Value and its Impact on the Global Financial Crisis', Master thesis, Business College, Middle East University

2. Christensen, HB and Nikoaev, VV. (2013), 'Does Fair Value Accounting for Non-Financial Assets Pass the Market Test,' Review of Accounting Studies, Forthcoming.
[Online], [Retrieved December 22, 2013], https://ssrn.com/abstract=1269515 or http://dx.doi.org/10.2139/ssrn.1269515

3. Ghazi, ABM. (2014), 'The Impact of the Transition to Application of the International Standard No.9 in the Measurement of Financial Instruments of the Banks Listed on the Damascus Stock Exchange,' Damascus University Journal of Economic and Legal Sciences, 1

4. IFRS at a glance IFRS 13 fair value measurement LBDO (Anon., 2014, p.1)

5. Jamil, HA. (2013), 'The Impact of Applying Fair Value Accounting on the Reliability and Appropriateness of the Financial Statement Information,' Jordanian Journal of Business Administration, 3(472)

6. Linde, E and Pedersen, JM. (2011), A Comparative Analysis between IAS39 \& IFRS9, Copenhagen Business School

7. Lutamila, S. (2009), CPA, CMA, CFM, CFE, CIA, FAIR VALUE Accounting, 1(2)

8. Mansour, FM. (2011), 'The Extent to which Electronic Commercial Banks are Committed to Applying Fair Value Standards to Financial Assets and Liabilities', Master thesis, Middle East University, 37

9. Mater, M., Nor, A. and Alfshe, D. (2009), 'Relationship between fair value standards and the global financial crisis.' Proceedings of the Third Scientific Conference, Jordan, University of Esra, 4-9-28

10.Safwan, QA., and Asma, AK. (2013), 'Revaluation of Property, Plant and Equipment at Fair Value in Accordance with IAS (16),' ALMuthanna Journal of Administrative and Economic, 6(4)

11.Zyod, L., Roda, A. and Lake (2007), 'Accounting Disclosures in the Financial Statements of Banks in Accordance with International Accounting Standard', Journal for Studies and Scientific Research, 30(2), Tishreen University. 